\title{
連載講座
}

I

\section{中性子回折の基礎と応用（応用 12）}

\section{中性子回折による創薬標的蛋白質の構造解析}

\author{
玉田太郎，安達基泰
}

独立行政法人 日本原子力研究開発機構

319-1195 茨城県那珂郡東海村白方白根 2-4

\begin{abstract}
$\mathrm{X}$ 線回折が原子核を取り卷く電子からの現象であるのに対し, 中性子回折は原子核そのものから 生じる回折現象である。したがって，同じ原子を観測してもその位置や見え方に特徴的な差が生じ る。水素原子の中性子散乱長は炭素や酸素原子などと同程度であるため, X 線結晶構造解析では $0.1 \mathrm{~nm}$ 以上の高分解能でなければ決定できない水素原子の位置を, 中性子結晶構造解析では通常 の分解能 $(0.2 \mathrm{~nm}$ 程度) で容易に決定できる。また，この二つの方法で観測される水素原子の位 置には違いがあり，特殊な環境に存在する酵素の触媒基の電子状態と原子核の位置にどのような違 いがあるのかは大変興味深い。このように中性子とX 線の特徴的な違いをうまく利用した構造解 析を行えば，蛋白質が関与するさまざまな生命反応をより梁く理解することが可能になると思われ る。最近, 筆者らは 2 例の創薬標的蛋白質と医薬品候補分子（阻害剂）複合体の中性子構造解析に 成功した。一つは HIV-1 プロテアーゼ/KNI-272 複合体，もう一つはブタ膵臓エラスターゼ/FR 130180 複合体であり，いずれの結果も X 線では観察が難しい触媒残基の解離状態を明らかにでき た。これらの知見は, 創薬標的酵素の触媒機構の理解を深めると共に, より効果的な治療薬の開発 に慗がるものと期待される。
\end{abstract}

Key Words : neutron diffraction, protein crystallography, structure based drug design (SBDD), neutron/X-ray joint refinement

\section{1. はじめに}

蛋白質には，様々な生命現象に関わる酵素と 呼ばれる分子触媒の仲間がある。ヒトやウイル スに由来するある種の酵素は疾病の原因となり， 医薬品が直接作用する蛋白質であることが知ら れる。これらの蛋白質を, 創薬標的蛋白質と呼 ぶ。創薬標的蛋白質の立体構造に基づく薬物設 計（Structure Based Drug Design:SBDD）は, 立体構造解析の発展と共に有効視され，1980 年代後半から, 医薬品開発研究の現場において 急速に定着してきた。例えば，抗 HIV 薬リト ナビル（プロテアーゼ阻害剤），慢性骨髄性白 血病治療薬グリベック, 抗悪性腫瘍薬イレッサ (いずれもキナーゼ阻害剤), 抗インフルエンザ 薬タミフル（ノイラミダーゼ阻害剤）といった
医薬品の短期開発に大きく貢献している。

現状の SBDD では, X 線結晶構造解析から 得られた立体構造情報を用いて, 薬物と薬物が 結合する蛋白質のポケットの形状及び性質を相 補させることに，特に注意が払われている。し かしながら, 通常の分解能 $(0.1 \mathrm{~nm}$ を下回る 分解能）での X 線解析では, ポケットに存在 し, 酵素活性をつかさどることが多い荷電性の アミノ酸（アスパラギン酸 (Asp), グルタミン 酸(Glu), ヒスチジン (His) 等) の水素原子の状 態 (解離状態) を知ることは難しい。X 線は, 原子核を取り巻く電子から散乱し, 各原子との 相互作用の強さは電子の数と比例するため, 他 の原子と比べて電子数の少ない水素原子を X 線で観測するのが原理的に困難であることによ る。一方，中性子は原子核そのものから散乱し， 
散乱の度合いは原子番号によらず個々の原子の 性質に由来しているため，水素原子による中性 子の散乱効果は他の元素と遜色なく，特に同位 体である重水素原子は，炭素原子と全く同等に 観測できる。これより，X 線解析では観測困難 な触媒残基の水素原子の状態を，中性子解析は 明らかにできることから，より高精度な SBDD への応用が期待される。

また，酵素と基質分子や薬物との相互作用に おいては，結合状態の構造ばかりに注目が集ま るが，基質が結合していない状態の立体構造に も重要な情報が存在する。それは，酵素の基質 結合部位に存在する水和水の立体構造である。 $\mathrm{X}$ 線解析においても，水和水の酸素原子の位置 を知ることができるが，水和水の二つの水素原 子の位置情報を知ることは難しい。日本原子力 研究所の茶竹 (現在は, 京都大学) らは, 中性 子回折により得られた水和水に由来する原子核 密度の分布図を詳しく観察し，その形に様々な

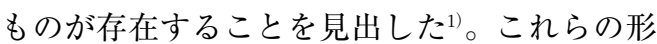
の違いは，蛋白質表面の水和水の分子運動の自 由度の違いを反映していると考えられるため, 中性子解析は水和水の位置情報だけではなく, その動的な特性も知ることができる。酵素が基 質分子や薬物と結合する際には脱水和を伴うが, 水和水の詳細な構造情報を知ることにより，脱 水和に必要なエネルギーを正しく見積もること ができるかもしれない。そうなれば，基質や薬 物の親和性をより正確に見積もることができる はずであり，中性子を用いた SBDD の新たな 展開が可能となる。

本解説では，最近筆者らが中性子解析に成功 した創薬標的蛋白質と医薬品候補分子（阻害 剂）複合体の構造解析結果を 2 例紹介する。一 つは HIV-1 プロテアーゼ/KNI-272 複合体 ${ }^{2}$,

もう一つはブタ膵臓エラスターゼ/FR130180 複合体 ${ }^{3)}$ の構造解析で，いずれの結果も X 線で は観察が難しい触媒残基の解離状態を明らかに できた。これらの知見は，創薬標的酵素の触媒 機構の理解を深めると共に，より効果的な治療
薬の開発に繋がるものと期待される。

\section{HIV-1 プロテァーゼ/KNI272 複合体の構 造解析}

$2 \cdot 1$ HIV-1 プロテアーゼ

HIV（ヒト免疫不全ウイルス）の感染者は, 世界に 4000 万人近くいると推定されている。 HIV は, 免疫細胞に感染し破壊することで, 後天性免疫不全症候群（エイズ）を引き起こす ことから，ウイルスの早期撲滅が切望されてい る。HIV-1 プロテアーゼは, HIV のタイプ 1 に存在する三つの酵素のうちの一つで，蛋白質 分解酵素として働いている。大きさとしては, 蛋白質の中では比較的小さく, アミノ酸 99 個 で形成する分子量約 10000 のポリペプチドが 二つ結合する 2 量体を形成し，機能を発揮して いる（二つのポリペプチドのアミノ酸残基番号 をここでは1-99 及び101-199 とする)。HIV-1 プロテアーゼは，ウイルスを構成する前駆体の ポリプロテイン（鎖状に繋がる蛋白質）が合成 された後に，それを切断することで個々の蛋白 質を完成させている。HIV-1 プロテアーゼはウ イルスの増殖に必須であることから，その機能 を抑制できれば，ウイルスの機能蛋白質は完成 しないため，ウイルスの形成や増殖を抑制でき ると考えられる。つまり，HIV-1 プロテアーゼ は創薬標的蛋白質であり，HIV-1 プロテアーゼ の触媒機構及びその阻害剂との相互作用様式の 解明が，抗エイズ薬（阻害剂）開発への重要な 知見となる。

$2 \cdot 2$ 試料調製, 結晶化及び構造解析

蛋白質の中性子結晶構造解析を実施する場合 には，均一で大型の結晶を作製する必要がある。 そのためには，できるだけ高純度の試料を大量 に調製する必要がある。しかしながら，一般に プロテアーゼのような蛋白質分解酵素では，自 己消化による試料の損失や宿主細胞の増殖が生 じるため，大量調製は容易ではない。

本研究では，まず大腸菌を用いた HIV-1 プ 
ロテアーゼの調製方法を確立した。最初に，大 腸菌内で，HIV-1 プロテアーゼが大量調製され るように最適化した HIV-1 プロテアーゼの遺 伝子配列を人工合成し，それを発現プラスミド に組み込んだ後に，大腸菌に形質導入した。発 現実験の結果, 不溶性の蛋白質（封入体）とし て大量発現していることを確認できたが，封入 体の状態では立体構造が形成されていない。そ こで, 機能を持った本来の構造に戻すための再 生処理が必要であった。様々な条件検討の結果, 効率よく再生する条件を確立することに成功し, 再生した HIV-1 プロテアーゼを更に精製した 後に，結晶化用試料として用いた。

これまでに，日本原子力研究開発機構（以下， 原子力機構）の研究用原子炉 JRR-3に設置さ れた，生体高分子用回折計 BIX-3 及び 4 にお いて実施された，種々の蛋白質結晶を用いた回 折実験の実績から, $0.2 \mathrm{~nm}$ 以上の分解能の中 性子回折デー夕を得るためには, 最低 $3 \mathrm{~mm}^{3}$ の HIV-1 プロテアーゼ結晶が必要であると推 定された。結晶の大型化に, 従来から用いられ ているマクロシーディング法と, 不活性溶液( フ ロリナート）を下層に，HIV-1 プロテアーゼを 含む結晶化母液を上層に, 置いた 2 液バッチ法 を組み合わせることにより, 最終的に $3.6 \mathrm{~mm}^{3}$ $(3.6 \times 2.0 \times 0.5 \mathrm{~mm}$ の板状 $)$ の HIV-1 プロテ アーゼ（KNI-272 複合体）結晶を得ることに成 功した4)。

中性子回折データの収集は, JRR-3 の BIX4 において実施した。通常は, バックグラウン ド軽減と水素原子のより明瞭な観察のために, 重水溶液に浸漬（若しくは結晶化自体を重水環 境で実施）させた蛋白質結晶を用いて中性子回 折実験を実施する。

HIV-1 プロテアーゼの結晶を, 活性が至適と なる pD 5.0 の重水溶液に 2 週間浸漬させた後 に, 石英キャピラリーに封緘し, 回折実験に供 した。回折デー夕収集には静止写真法を用い, 回折イメージ 1 枚あたり 6 時間露光し， 0.3 度 ずつ結晶を回転させることにより, 計 181 フレ
ームの回折イメージを室温下で収集した。また， 中性子回折実験後に，同一結晶を用いて高エネ ルギー加速器機構・Photon FactoryのBL6Aに おいて, X 線回折デー夕の収集も併せて室温下 で実施し, 最終的に $0.19 \mathrm{~nm}$ 分解能の中性子 回折デー夕及び $0.14 \mathrm{~nm}$ 分解能の $\mathrm{X}$ 線回折デ ータを得た。

得られた中性子及び X 線の回折デー夕を用 いて，プログラム PHENIX $^{5}$ により同時精密化 を実施した。この方法は，一つの構造（座標デ 一夕）を中性子及びX線の両方の回折データ に対してフィットさせることにより, 中性子単 独のデー夕を精密化したときに比べて，よりモ デルバイアスの小さい精密化を実施することが 可能となる。精密化終了後の HIV-1 プロテア 一ゼ/KNI-272 複合体全体構造を図 1 に示す。 2111 個の水素原子（内 520 個は重水素）と重 水 143 分子を含む HIV-1 プロテアーゼ/KNI272 複合体全原子立体構造の決定に成功した。

また，別途作製した結晶を用いて， SPring一 8 の BL41XUにおいて $0.093 \mathrm{~nm}$ 分解能のX 線回折データを $100 \mathrm{~K}$ 下で収集した。0.093 nm 分解能の高分解能解析の際には, 中性子解析で 得られたグルタミン及びアスパラギン残基の側 鎖の方向等の情報を反映しつつ，構造解析を完 了した。

\section{2・3ＨIV-1 プロテアーゼの活性中心の構造}

本研究で結晶化に使用した阻害剂 KNI-272 は，カルボニルメチルヒドロキシという特徵的 な構造を持つ化合物で, HIV-1 プロテアーゼの 阻害活性が強く，阻害剂設計のための基礎情報 が得られやすい。更に, KNI-272 は遷移状態ア ナログであるために, 触媒機構の解明に有効な 阻害剤である。0.19 nm 分解能で決定された HIV-1 プロテアーゼ/KNI-272 複合体の X 線結 晶構造（水素原子は含まれていない）を基にし た量子化学計算によって, 活性中心の Asp25 残基の $\mathrm{O} \delta 2^{*}$ 原子がプロトン化されていること が示唆された ${ }^{6)}$ 。この推察は，同複合体を用い 


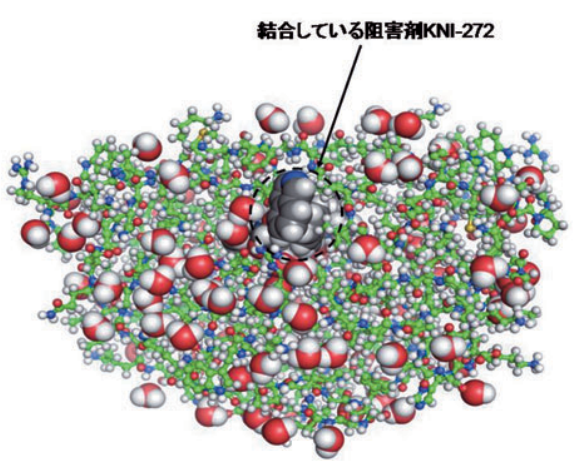

図 1 中性子結晶構造解析によって明らかにな った HIV-1 プロテアーゼと KNI-272 との 複合体の全体構造。結合している阻害剤 と水分子を大きい球で示す。水素及び重 水素 (白), 炭素 (緑及び黒), 窒素 (青), 酸素 (赤), 硫黄 (黄) 原子。

て実施された NMR 解析結果と一致していた7)。 しかし，それに反して ab initio 計算の結果を 基に，両方の触媒残基がプロトン化されている という説も提唱されており ${ }^{8)}$, HIV-1 プロテア 一ゼの活性中心の触媒基の解離状態についての 論争が続いていた。

図 2 に, 今回中性子構造解析で決定した HIV1 プロテアーゼ/KNI-272 複合体の活性中心の 構造を示す。中性子解析の結果，Asp25 残基 の $\mathrm{O} \delta 2$ 原子がプロトン化され, 阻害剤 KNI-272 のカルボニル基との間で, 比較的強い水素結合 を形成していることが実験的に明らかになった。 また, KNI-272のヒドロキシル基の水素原子 （DO2）が観察され，プロトン化されていない Asp25 と水素結合を形成していることも明ら かとなった。

一方, $0.093 \mathrm{~nm}$ の高分解能 X 線結晶構造解 析の結果では, 有意な水素原子由来の電子密度 は得られなかったが，結合長から触媒残基の解 離状態に関して重要な情報が得られた。Asp

*アミノ酸は中心の $\alpha$ 炭素を基準に側鎖方向に $\beta$, $\gamma \cdots$ の順で原子を命名する。アスパラギン酸 (Asp) は $\delta$ 位に二つの酸素原子があり, 各々 $\delta 1, \delta 2$ と 命名されている。

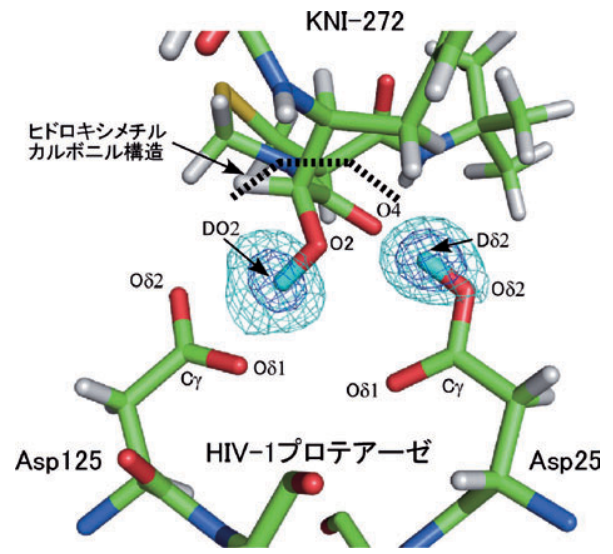

図 2 HIV-1 プロテアーゼ触媒残基近傍の水素 原子。図の上側が阻害剂 KNI-272で, 下 側が HIV-1 プロテアーゼの触媒残基 (Asp 25 及び Asp125）部分。 $F_{\mathrm{O}}-F \mathrm{C}$ 差フーリ エ（二つの水素原子をモデルに含まな い）計算した核密度散乱分布を $3 \sigma$ （水

色）及び $5 \sigma$ (青) レベルで表示している。

25 の $\mathrm{O} \delta 1$ と $\mathrm{C} \gamma$ の原子間の距離を計算したと ころ $0.120 \mathrm{~nm}$ であったのに対し, $\mathrm{O} \delta 2$ と $\mathrm{C} \gamma$ の原子間の距離は $0.132 \mathrm{~nm}$ と約 $0.01 \mathrm{~nm}$ 長か った。一方でAsp125については，それぞれ $0.126 \mathrm{~nm}$ と $0.125 \mathrm{~nm}$ で有意な差はなかった。 これらは，Asp25の O $\delta 2$ がプロトン化され， Asp125 はプロトン化されていないことを示し ており, 中性子結晶構造解析の結果と一致して いた。

\section{$2 \cdot 4 \quad \mathrm{HIV}-1$ プロテアーゼの触媒機構}

HIV-1 プロテアーゼの触媒機構については, 同じ酸性プロテアーゼで古くから研究されてい るペプシンをモデルとして考えられており，一 般酸塩基触媒が考えられていた。しかしながら， 最近になって, 二つの触媒残基の解離定数が近 いこと, 活性の至適 $\mathrm{pH}$ （pD）に対する同位体 効果から，低障壁水素結合が，二つの触媒残基 の間に存在することが提唱された 後, $0.165 \mathrm{~nm}$ 分解能における X 線結晶構造解 析結果からも, HIV-1 プロテアーゼと生成物複 合体において酸素原子 $(\mathrm{O} \delta 1)$ 間の距離が近い ことから低障壁水素結合 (low barrier hydrogen 
bond : LBHB) が形成されていると報告された ${ }^{10)}$ 。 しかしながら，今回の HIV-1 プロテアーゼ/ KNI-272 複合体の中性子結晶構造解析において は，二つの触媒残基の間には水素原子は観測さ れず，低障壁水素結合の形成を支持するもので はなかった。一方, KNI-272 のカルボニル基と Asp25 間で確認された相互作用が, 分解され る基質のカルボニル基 Asp25 の相互作用を反 映し, KNI-272 の水酸基の酸素原子が加水分解 反応で基質に攻撃する水分子を反映している構 造であると考えられ, Asp25 が水分子を活性 化する塩基触媒として機能していることが推察 された。つまり，今回の中性子構造解析から， HIV-1 プロテアーゼの触媒反応においては Asp 25 が酸触媒として, Asp125 が塩基触媒として 加水分解に使われる水分子を活性化している機 構が提唱できた。

以上のように, 中性子結晶構造解析によって 明確な水素原子の情報を得ることは, HIV-1 プ ロテアーゼの触媒反応機構の解明に非常に有効 であった。また，水素原子の構造情報を得るこ とで, 触媒残基の解離状態が明らかとなり, よ り親和性の高い阻害剂の精密分子設計が可能と なった。本酵素に重要でしかも保存性の高い部 分に強く結合する阻害剤が開発できれば，問題 となっている薬剤耐性ウイルスにも有効と考え られる。

\section{3. ブタ膵蔵エラスターゼ/FR130180 複合体 の構造解析}

\section{$3 \cdot 1$ エラスターゼ}

エラスターゼは, SBDD 研究の代表的な題 材として用いられてきたセリンプロテアーゼで ある。好中球エラスターゼに対する阻害剂は, 全身性炎症反応症候群に対する急性肺障害の治 療薬として小野薬品工業よりエラスポール（一 般名シベレスタット）が実際に上市されている。 また, 種々の原因により膵臓自体の防御機構が 破壊された時に，膵臓エラスターゼが膵臓の自 己消化を起こし, その結果, 急性荤炎, 引いて
は腎不全，呼吸不全をも発症させることも知ら れている。上記のように，これまでエラスター ゼの X 線結晶構造に基づいた多くの SBDD 研 究が実施されてきたが，それでもなお特異性の 高い阻害剂の作製が困難であるのが現状である。

セリンプロテアーゼの触媒機構においては, 「低障壁水素結合 (LBHB) 仮説」が提唱され

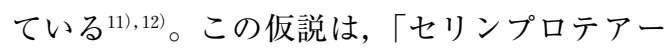
ゼの活性中心に存在するヒスチジン，アスパラ ギン酸，セリンからなる触媒三つ組残基のうち, ヒスチジンとアスパラギン酸の側鎖間に形成さ れるLBHBにより，遷移状態を安定化される ことが反応障壁の低下に重要である」というも のである。この仮説はスブチリシンの $0.078 \mathrm{~nm}$ 分解能における X 線結晶構造解析 ${ }^{13)}$ やキモト リプシンの NMR 解析 ${ }^{12)}$ の結果により支持され ている一方で, $\alpha$-溶菌プロテアーゼのX 線 ${ }^{14)}{ }^{15)}$ 及び NMR 解析 ${ }^{16)}$, 更にスブチリシンの NMR 解析 ${ }^{17)}$ の結果からは LBHB の形成が否定 されており，いまだ論争中である。

これらの現状を踏まえ, エラスターゼの全原 子構造情報からの SBDD 研究の新展開, 及び セリンプロテアーゼの触媒機構解明を目指し, ブタ膵臓由来のエラスターゼ (Porcine Pancreatic Elastase : PPE) と, その阻害剤 (FR130180) の中性子結晶構造解析及び超高分解能 $\mathrm{X}$ 線結 晶構造解析を実施した。

\section{$3 \cdot 2$ 結晶化及び構造解析}

結晶化には，市販の PPE (Worthington Biochemicals 社）とアステラス製薬から供与され た阻害剂 FR130180を用い, 既知の結晶化条件 近辺で共結晶化法により複合体結晶を作製した。 中性子回折実験を念頭に, 結晶化は重水及び重 水素化試薬を用いて実施した。取得した結晶に 蛋白質（複合体）溶液を逐次添加することによ る中性子回折実験用の大型結晶取得を試み，約 4 か月間逐次添加を継続した結果, 最終的に 3.9 $\mathrm{mm}^{3}(2.9 \times 1.4 \times 1.2 \mathrm{~mm})$ の PPE（FR130180 複合体）結晶を得ることに成功した ${ }^{18)}$ 。 


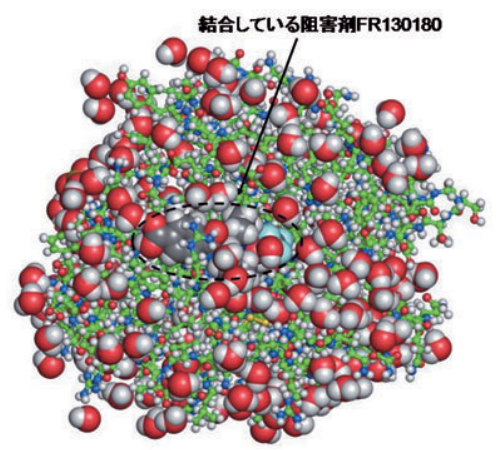

図 3 中性子結晶構造解析によって明 らかになったエラスターゼと阻 害剂 FR130180 との複合体の全体 構造。結合している阻害片と水 分子を大きい球モデルで示す。 水素及び重水素 (白), 炭素 (緑 及び黒), 窒素 (青), 酸素 (赤), 硫黄 (黄), フッ素 (水色) 原子。

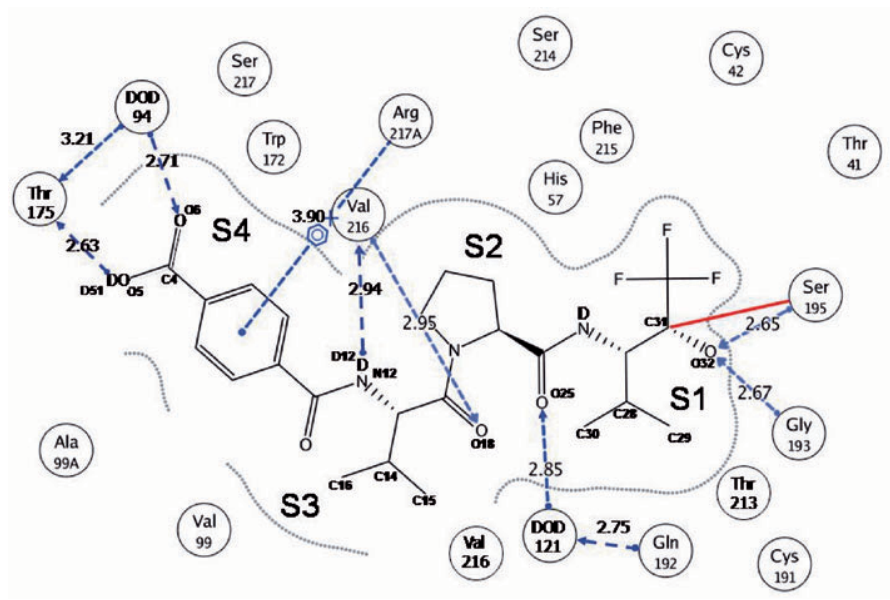

図 4 阻害剤 FR130180 とエラスターゼ間の相互作用。FR130180 は構 造式で表示。水素結合を点線（青・矢印），カチオン $-\pi$ 相互作 用を点線（青・ベンゼン環・プラス），共有結合を実線（赤）で 示す。プログラム MOE（カナダ CCG 社）で作図した。
中性子回折データの収集は JRR-3 の BIX-3 において実施した。回折データ収集は振動写真 法（回転角 0.3 度）を用い，回折イメージ 1 枚 あたり 4 時間露光し, 2 方向から計 556 フレー ムの回折イメージを室温下で収集した。また, HIV-1 プロテアーゼの際と同様に, 中性子回折 実験後の同一結晶を用いて, Photon Factory の BL6A においてX 線回折データの収集も併せ て室温下で実施し, 最終的に $0.165 \mathrm{~nm}$ 分解能 の中性子回折データ及び $0.12 \mathrm{~nm}$ 分解能の $\mathrm{X}$ 線回折デー夕を得た。精密化はプログラム PHENIX による同時精密化法により実施し, PPE/FR130180 複合体構造解析を完了した。 全体構造を図 3 に示す。全体の約半分を占める 2062 個の水素原子（内 435 個は重水素）と, 重水 190 分子を含む PPE/FR130180 複合体全 原子立体構造の決定に成功した。また, SPring8 の BL41XUに打いて超高分解能 X 線構造解 析用の回折デー夕収集を $100 \mathrm{~K}$ 下で別途実施 し, $0.094 \mathrm{~nm}$ 分解能の複合体構造を決定した。

\section{3 •3 PPE の阻害剂認識様式}

阻害剂 FR130180 の構造式を, 阻害剤認識に 関与している PPEのアミノ酸残基とともに模
式的に表したものが図 4 である。FR130180 は, エラスターゼの基質を模倣したペプチド様の化 合物であり，PPE はFR130180を本来の基質 ペプチド同様に四つのサブサイト $(\mathrm{S} 1 ＼textrm{S} 4)$ で認識している。S1 サブサイトでは，イソプ ロピル基（図 4 中の C28〜 C30）と Thr213 と Val216の側鎖の間に，蛋白質の分子認識の基 本モチーフの一つである「ロイシンジッパー」 様の相互作用が形成されていた。S 1 サブサイ トは，セリンプロテアーゼの基質認識において 最も特異性を創出している箇所であり, エラス ターゼは，ここで小さな中性残基（グリシン, アラニン，セリン，バリン）を特異的に認識し ている。FR130180 中のこのイソプロピル基は, バリン残基の側鎖に相当しており，基質認識の 際にも同様の相互作用が機能していると推察さ れた。

S2 サブサイトでは, Gln192 の側鎖とアミノ カルボニル基の酸素原子（O25）が，水分子を 介した水素結合を形成していた。 33 サブサイ トでは，Val216の主鎖のアミド及びカルボニ ル基と, FR130180 中のもう一つのイソプロピ ル基（C14〜 C16）近傍のカルボニル（O18） 及びアミド（N12D12）基間の水素結合により, 
(a)

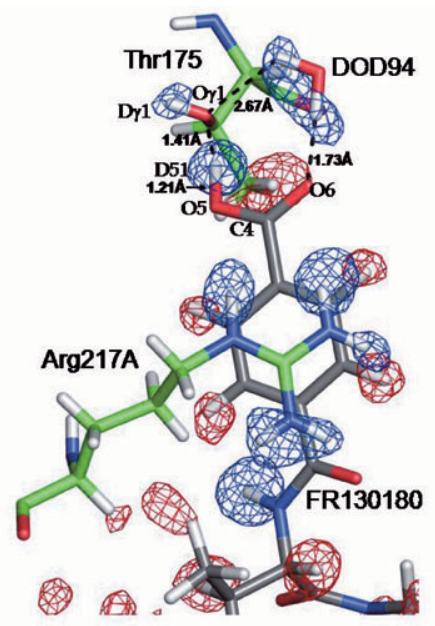

(b)

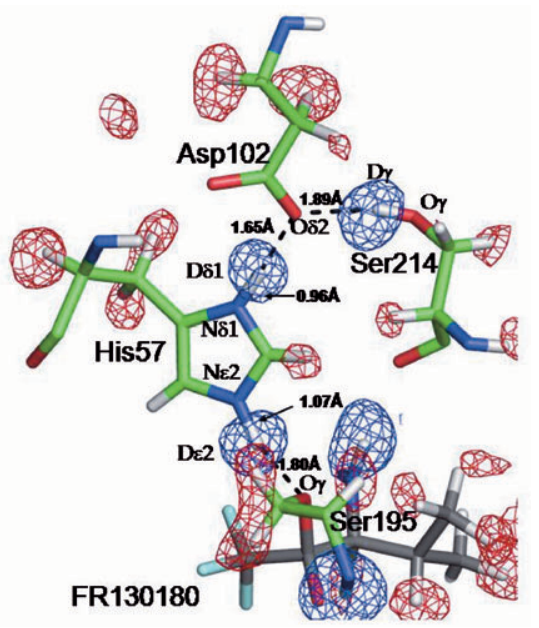

(c)

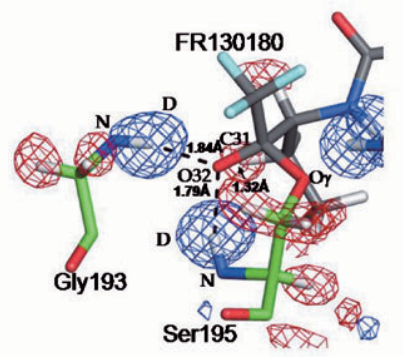

図 5 エラスターゼ/FR130180 複合体の $F \mathrm{O}^{-}-\mathrm{Fc}$ 差フ ーリエ核密度散乱分布図。(a)S4 サブサイト,

(b)触媒三つ組残基，(c)オキシアニオンホー ル，近傍を表示。 $+5 \sigma$ （青: 重水素）及び $-4.5 \sigma$ (赤: 軽水素) レベルで表示している。
PPE と FR130180間に逆平行 $\beta$ シートが形成 されていた。セリンプロテアーゼと基質のペプ チド間においても, 逆平行 $\beta$ シートが形成さ れることは知られており，基質認識と同様の様 式で阻害剤認識が行われていた。

S4 サブサイトでは，二つの特徴的な阻害剂 認識機構が観察された（図 5a）。一つは, Arg 217A の側鎖中のグアニジノ基と FR130180 の 安息香酸部分に形成されたカチオンー $\pi$ 相互作 用である。カチオン $\pi$ 相互作用は $\pi-\pi$ 相互 作用に比べて強く, 新なな相互作用として近年 興味が持たれている。複合体構造中のPPEの グアニジノ基と，FR130180 の安息香酸部分は， ほぼ平行に位置しており，更に中性子構造解析 で得られた核密度散乱分布から，グアニジノ基 が正電荷を帯びたカチオンの状態であることが わかり，阻害剂認識にカチオンー $\pi$ 相互作用が 関与していることが判明した。もう一つは, Thr175 の側鎖と, FR130180の安息香酸中の カルボキシル基間に形成された水素結合ネット ワークである。本複合体の結晶化は pD 5.0 下 で実施しているため, カルボン酸は通常解離状 態であると考えられる。しかしながら, 得られ た核密度散乱分布は, 安息香酸中のカルボキシ ル基がプロトン化しており，重水素原子(D51) は通常よりも長い O-D 距離 $(0.121 \mathrm{~nm})$ で, カルボキシル基の 05 原子と Thr175 の側鎖の $\mathrm{O} \gamma$ 原子の間に位置していることを明らかにし た。また, カルボキシル基の 06 原子も, 水(重 水）分子を介して Thr175 の側鎖と水素結合を 形成していた。この水素結合ネットワークは, 強力な水素結合として知られている共鳴支援水 素結合の特徴を有しており，阻害剤認識に深く 関わっていると思われる。

\section{$3 \cdot 4 \quad \mathrm{PPE}$ の活性中心の構造}

先に述べたように，セリンプロテアーゼの触 媒機構において，LBHB 仮説はいまなお論争中 である。今回決定した PPE/FR130180 複合体 は，セリンプロテアーゼの触媒機構の初期段階 
で形成される正四面体型遷移中間状態を模倣し ており(詳細は後述)，LBHB 仮説の検証に適 した構造である。中性子及び超高分解能 X 線 構造において，ヒスチジン（His57）とアスパ ラギン酸（Asp102）の側鎖間の水素結合の距 離（His57N $\delta 1-A s p 102 \mathrm{O} \delta 2 ） は 0.260 \mathrm{~nm}$ で, LBHB 形成を支持する短い水素結合距離であっ た。しかしながら，中性子解析から得られた核 密度散乱分布は, His57 が二重プロトン化状態 であることを明瞭に示したが (図 $5 \mathrm{~b}$ ), His $57 \mathrm{~N} \delta$ $1-\mathrm{Asp} 102 \mathrm{O} \delta 2$ 間に存在する（重）水素原子 （D $\delta 1 ） は ， H i s 57$ に通常距離で結合しており， ドナーとアクセプターの中間付近に存在すると いう，LBHB の特徵を充たすものではなかった。 中性子解析ほど明瞭ではなかったが, 超高分解 能 X 線解析から得られた電子密度からも同様 の水素原子位置が観察されており, $\mathrm{PPE} / \mathrm{FR}$ 130180 複合体の His57-Asp102 間で確認した 水素結合は LBHB ではなく, 短いイオン性水 素結合 (short ionic hydrogen bond: SIHB) で あり，LBHB 仮説を否定するものであった。

セリンプロテアーゼの正四面体型遷移中間状 態においては, 基質ペプチドの切断末端のカル ボニル基の炭素原子が，触媒三つ組残基のうち のセリン残基の側鎖の酸素原子と共有結合する。 この際に, ペプチド中のカルボニル基が本来持 つ平面三角形構造が正四面体構造に変化する。 カルボニル基の酸素原子は, 主鎖の二つのアミ ド基から作られる「オキシアニオンホール」に はまり込み，正四面体型遷移中間状態が安定化 されると考えられている。オキシアニオンの名 のとおり, カルボニル酸素は酸素陰イオンとし てオキシアニオンホールに存在すると考えられ ているが，実際にその状態を観察した例は， これまでに報告されていない。今回決定した PPE/FR130180 複合体構造において, 阻害剂 のトリフルオロメチル末端の隣のオキソプロピ ル基は基質ペプチド切断末端のカルボニル基を 模倣している。カルボニル炭素（C31）は，七 リン（Ser195）の O $\gamma$ 原子と共有結合を形成し，
正四面体構造の中心に位置していた（図 5c）。 核密度散乱分布は，Gly193 と Ser195 の主鎖の アミド基の（重）水素原子位置を明瞭に示し， 阻害剂のカルボニル酸素（O32）は，これら二 つの水素原子から構成されたオキシアニオンホ ールに位置していた。O32の周りには，この酸 素原子に付加した如何なる（重）水素原子由来 の核散乱密度分布も存在しておらず，オキシア ニオンホールに位置した酸素原子は，水酸基で はなく確かに酸素陰イオンの状態であることを 実験的に初めて観測できた。この観測は，超高 分解能 X 線解析から求まった C31-O32 間の精 緻な距離 $(0.132 \mathrm{~nm})$ がカルボニル基中の標 準距離 $(\mathrm{C}=\mathrm{O}: 0.121 \mathrm{~nm})$ よりも長く, 水酸 基の場合（C-OH：0.143 nm）より短いことか らも支持された。

\section{4. おわりに}

中性子が有する「水素（重水素）原子を直接 観測できる」という特徵は，これまで困難であ った水素原子の情報も含む蛋白質の全原子構造 決定を可能にする。筆者らは, 中性子構造解析 の手法を有効に使える研究対象の一つが，創薬 標的蛋白質であると考えている。これまでは技 術的な問題からその報告例は少なかったが，昨 年末から稼働を開始した J-PARCの利用と， 試料調製・結晶化技術開発の進展から，中性子 解析が X 線解析とともに, 蛋白質の一般的な 構造解析手法として利用される日は，すぐ近く まで来ている。また，本解説で述べたように， 中性子とX 線を個別ではなく相補的に用いる ことにより，ょり多くかつ正確な情報が得られ る。今後, 中性子による蛋白質の構造解析例が 増加するにつれて, 蛋白質の立体構造形成や分 子認識・反応機構に関する新たな発見がなされ るであろう。更に，これらの発見は，有用分子 （創薬標的蛋白質においては医薬品）の創製へ と展開していくと期待される。 


\section{謝 辞}

本解説で紹介した 2 例の中性子構造解析は, いずれも日本原子力研究開発機構量子ビーム応 用研究部門生体分子構造機能研究グループ（黒 木良太グループリーダー）において実施された。

HIV-1 プロテアーゼ/KNI-272 複合体の中性 子構造解析は, 大阪大学大学院工学研究科電気 電子情報工学専攻 (森勇介教授), 京都薬科大 学創薬科学系薬品化学分野 (木曽良明教授) 及 び株式会社創晶（代表取締役社長安達宏昭氏） と，また，ブタ膵臓エラスターゼ/FR130180 複合体の中性子構造解析は大阪府立大学大学院 理学研究科生物科学専攻 (木下誉富准教授) と 共同で実施した。本研究に携わった数多くの 方々に御礼申し上げる。

\section{文献}

1) Chatake, T., Kurihara, K., Tanaka, I., Tsyba, I., Bau, R., Jenney, F.E. Jr., Adams, M.W. and Niimura, N., A neutron crystallographic analysis of a rubredoxin mutant at $1.6 \AA$ resolution, Acta Crystallogr., D60, 1364-1373 (2004)

2) Adachi, M., Ohhara, T., Kurihara, K., Tamada, T., Honjo, E., Okazaki, N., Arai, S., Shoyama, Y., Kimura, K., Matsumura, H., Sugiyama, S., Adachi, H., Takano, K., Mori, Y., Hidaka, K., Kimura, T., Hayashi, Y., Kiso, Y. and Kuroki, R., Structure of HIV-1 protease in complex with potent inhibitor KNI-272 determined by high-resolution X-ray and neutron crystallography, Proc. Natl. Acad. Sci. USA, 106, 4641-4646 (2009)

3) Tamada, T., Kinoshita, T., Kurihara, K., Adachi, M., Ohhara, T., Imai, K., Kuroki, R. and Tada, T., Combined high-resolution neutron and X-ray analysis of inhibited elastase confirms the activesite oxyanion hole but rules against a low-barrier hydrogen bond, J. Am. Chem. Soc., 131, 1103311040 (2009)

4) Matsumura, H., Adachi, M., Sugiyama, S., Okada, S., Yamakami, M., Tamada, T., Hidaka, K., Hayashi, Y., Kimura, T., Kiso, Y., Kitatani, T., Maki, S., Yoshikawa, H.Y., Adachi, H., Takano, K.,
Murakami, S., Inoue, T., Kuroki, R. and Mori, Y., Crystallization and preliminary neutron diffraction studies of HIV-1 protease cocrystallized with inhibitor KNI-272, Acta Crystallogr., F64, 1003-1006 (2008)

5) Adams, P.D., Grosse-Kunstleve, R.W., Hung, L.W., Ioerger, T.R., McCoy, A.J., Moriarty, N.W., Read, R.J., Sacchettini, J.C., Sauter, N.K. and Terwillinger, T.C., PHENIX: building new software for automated crystallographic structure determination, Acta Crystallogr., D58, 1948-1954(2002)

6) Baldwin, E.T., Bhat, T.N., Gulnik, S., Liu, B., Topol, I.A., Kiso, Y., Mimoto, T., Mitsuya, H. and Erickson, J.W., Structure of HIV-1 protease with KNI272 , a tight-binding transition-state analog containing allophenylnorstatine, Structure, 3, 581-590 (1995)

7) Wang, Y.X., Freedberg, D.I., Yamazaki, T., Wingfield, P.T., Stahl, S.J., Kaufman, J.D., Kiso, Y. and Torchia, D.A., Solution NMR evidence that the HIV-1 protease catalytic aspartyl groups have different ionization states in the complex formed with the asymmetric drug KNI-272, Biochemistry, 35, 9945-9950 (1996)

8) Piana, S., Sebastiani, D., Carloni, P. and Parrinello, M., Ab initio molecular dynamics-based assignment of the protonation state of pepstatin A/ HIV-1 protease cleavage site, J. Am. Chem. Soc., 123, 8730-8737 (2001)

9) Northrop, D.B., Follow the protons: A low-barrier hydrogen bond unifies the mechanisms of the aspartic proteases, Follow the protons: a low-barrier hydrogen bond unifies the mechanisms of the aspartic proteases, Acc. Chem. Res., 34, 790-797 (2001)

10) Das, A., Prashar, V., Mahale, S., Serre, L., Ferrer, J.L. and Hosur, M.V., Crystal structure of HIV-1 protease in situ product complex and observation of a low-barrier hydrogen bond between catalytic aspartates, Proc. Natl. Acad. Sci. USA, 103, 18464-18469 (2006)

11) Cleland, W.W. and Kreevoy, M.M., Low-barrier hydrogen bonds and enzymic catalysis, Science, 264, 1887-1890 (1994)

12) Frey, P.A., Whitt, S.A. and Tobin, J.B., A low-bar- 
rier hydrogen bond in the catalytic triad of serine proteases, Science, 264, 1927-1930 (1994)

13) Kuhn, P., Knapp, M., Solitis, S.M., Ganshaw, G., Thoene, M. and Bott, M., The $0.78 \AA$ structure of a serine protease: Bacillus lentus subtilisin, Biochemistry, 37, 13446-13452 (1998)

14) Fuhrmann, C.N., Kelch, B.A., Ota, N. and Agard, D.A., The $0.83 \AA$ resolution crystal structure of alpha-lytic protease reveals the detailed structure of the active site and identifies a source of conformational strain, J. Mol. Biol., 338, 999-1013 (2004)

15) Fuhrmann, C.N., Daughety, M.D. and Agard, D. A., Subangstrom crystallography reveals that short ionic hydrogen bonds, and not a His-Asp low-barrier hydrogen bond, stabilize the transition state in serine protease catalysis, $J . A m$. Chem. Soc., 128, 9086-9102 (2006)

16) Ash, E.L., Sudmeier, J.L., De Fabo, E.C. and Bachovchin, W.W., A low-barrier hydrogen bond in the catalytic triad of serine proteases? Theory versus experiment, Science, 278, 1128-1132 (1998)

17) Ash, E.L., Sudmeier, J.L., Day, R.M., Vincent, M., Torchilin, E.V., Haddad, K.C., Bradshaw, E.W., Sanford, D.G. and Bachovchin, W.W., Unusual ${ }^{1} \mathrm{H}$ NMR chemical shifts support $($ His $) C^{\varepsilon 1 \cdots} \mathrm{O}==\mathrm{C}$ H-bond: proposal for reaction-driven ring flip mechanism in serine protease catalysis, Proc. Natl. Acad. Sci. USA, 97, 10371-10376 (2000)

18) Kinoshita, T., Tamada, T., Imai, K., Kurihara, K., Ohhara, T., Tada, T. and Kuroki, R., Crystallization of porcine pancreatic elastase and a preliminary neutron diffraction experiment, Acta Crystallogr., F63, 315-317 (2007)

\section{Abstract}

Fundamentals and Applications of Neutron Diffraction (Applications 12).

Structure Determination of Drug Target Proteins by Neutron Crystallography

Taro TAMADA and Motoyasu ADACHI : Japan Atomic Energy Agency, 2-4 Shirakata-Shirane, Tokai-mura, Naka-gun, Ibaraki Pref. 319-1195, Japan

High resolution $X$-ray crystallography provides information for most of the atoms comprising the proteins, with the exception of hydrogen atoms. Whereas, neutron crystallography, which is a powerful technique for locating hydrogen atoms, enables us to obtain accurate atomic positions within proteins. Neutron diffraction data can provide information of the location of hydrogen atoms to the structural information determined by X-ray crystallography. Here, we show the recent results of the structural determination of drug-target proteins, porcine pancreatic elastase and human immuno-deficiency virus type-1 protease by both X-ray and neutron diffraction. The structure of porcine pancreatic elastase with its potent inhibitor was determined to $0.094 \mathrm{~nm}$ resolution by $X$-ray diffraction and $0.165 \mathrm{~nm}$ resolution by neutron diffraction. The structure of HIV-PR with its potent inhibitor was also determined to $0.093 \mathrm{~nm}$ resolution by $X$-ray diffraction and $0.19 \mathrm{~nm}$ resolution by neutron diffraction. The ionization state and the location of hydrogen atoms of the catalytic residue in these enzymes were determined by neutron diffraction. Furthermore, collaborative use of both $X$-ray and neutron crystallography to identify the location of ambiguous hydrogen atoms will be shown. 